\title{
Impact of Globalization on Higher Education in \\ Pakistan: Challenges and Opportunities
}

\author{
${ }^{1}$ Salma Naz
}

\begin{abstract}
Globalization, a process of interconnectedness of people and higher education, has a prominent position in intellectual society of this globalized world. Technological advancement has made possible access to knowledge and not restricted to physical boundaries. This cohesiveness has also an impact on higher education in Pakistan. Being a developing country it is earning fewer benefits from globalization as compared to developed nations. Moreover, Pakistan is also under cumbersome pressure to implement policies of powerful states in all fields of life including higher education. Since this globalized world has pros as well as cons so, in Pakistan where on one hand it has played positive role in development of research, improvement of knowledge and ability of teachers and students, enhancement of skills, betterment in quality of education, expansion of job market, etc. It has also imparted negative effects like brain drain, commercialization of knowledge instead of propagation of knowledge, ignorance of national needs in educational policies, promotion of academic imperialism and global citizenship instead of nationalism in Pakistan. No doubt, according to social Darwinism adaptation is prerequisite for survival, thus, for competing with global change higher education policy should be designed in the context of globalization, however, national needs should be given priority. The study is qualitative in nature and explores how globalization has not only created opportunities but has also posed challenges in perspective of higher education in Pakistan. This study also gives some recommendations through which Pakistan can meet aforementioned challenges successfully.
\end{abstract}

Keywords: Globalization, Higher education, interconnectedness, challenges, opportunities

\section{Introduction}

Globalization, a multifaceted concept has become burning issue in the new millennium. Because of different history, traditions, culture, resources and priorities countries have influenced differently. Some nations have made prominent position in this globalized world and have twisted the negative impact

\footnotetext{
${ }^{1}$ Chairperson/Coordinator Behavioral Science/History \& Pakistan Studies Faculty of Humanities, Minhaj University, Lahore Email: salmanoorshahid@gmail.com
} 
of globalization in their favor. Globalized world is more beneficial for developed as compared to developing nations. Because of less informed and less equipped they often stand in a disadvantageous position. This trend can also be observed even in their educational policies and planning. Being a developing country, education especially higher education in Pakistan is also under the influence of developed world. So, Pakistan is also facing more challenges as compared to opportunities in perspective of higher education.

In new millennium globalization is the most prominent and significant characteristic of global affairs that intensely affects the world. It brings change in the social, economic and cultural as well as political sphere. It is characterized by immense flow of information, growth of communication, economic activities and amalgamation of cultures(Crawford,2003).Most observers think that the capability to extract the positive impact from globalization and avoid the negative depends upon promotion of knowledge (Shahidi \& Seyedi,2012). Being developing country Pakistan has also great impact of globalization on its education especially on higher education. It has influenced higher education in Pakistan positively as well as brought some challenges. Pakistan can face these challenges with better planning and extract more benefits as compared to disadvantages in order to compete in globalized world.

This research is significant for understanding the impact of globalization regarding higher education in Pakistan. This research may helpful for education policy makers about higher education and may have practical importance for higher education policy and implementation in Pakistan.

\subsection{Objectives of Study}

1. To identify the opportunities created by globalization in perspective of higher education in Pakistan.

2. To explore the challenges posed by globalization for higher education in Pakistan.

\subsection{Research Questions}

1. How globalization has created opportunities in perspective of higher education in Pakistan?

2. What challenges globalization has brought for higher education in Pakistan?

\subsection{Delimitation of Study}

This study is only limited to Pakistan and focuses only pros and cons of globalization in perspective of higher education. Its conclusion may be limited to higher education in Pakistan. So, there is no assurance of application of conclusion of this research to another perspective or state. 


\section{Literature Review}

Reforms in higher education in Pakistan are under influence of neoliberal policies that has changed the role of higher education institutions as well as influenced policy making. But when the problems of quality and quantity arise through privatization and self-financing these problems tried to solve that damaged concept of higher education as public good and socially, politically and economically brought harmful results for society (Omar, 2006). This research only discusses the impact of globalization on educational policies and privatization of education but has ignored other challenges like brain drain ignorance of local needs etc. In this way research gap has been left by author. So, further research is required to explore the further aspects of higher education in perspective of higher education in Pakistan.

The study of Ali (2005) describes the different types of globalization and was of the opinion that it is more beneficial for developed countries as compared to developing because they are backward in technology, and are economically less developed. So, it is favored by advanced nations. In this globalized world policy making has become a complicated process under such circumstances developing countries are bearing the pressure of international agencies and powerful states to fulfill the demands of globalization instead of their national requirements.

In above mentioned background this article focuses the impact of globalization on educational policies of developing countries. In this study writer discusses how developed states influence the policies particularly educational policies of developing nations to accomplish their interests. In this paper author has only discussed the educational policies and ignored other aspects of education those have been influenced by globalization.

Study of Celik \& Gomleksi (2000) evaluates the effects of globalization on education. Researcher explains the advantages of globalization for individuals and institutions. This study explores the benefits of globalized world generally but does not discuss the issues those are related with globalization. Author generally describes advantages of cohesiveness of world and its impact on education but does not specifically analyze how globalization influenced negatively on higher education and leave research gap for further study.

Report of The Task Force on Higher Education and Society (Mundial, 2000), describes that because of prevalence of wrong assumption that higher education is not need of developing countries but luxury promotion of higher education was neglected by these countries. In this report it is declared that higher education should not be considered lavishness but necessity for existence because these countries require qualified and skilled persons for knowledge base 
economy. This study highlights the importance of higher education for developing nations but does not discuss the challenges of globalization for higher education for these countries. So, this report only presents importance of higher education for developing countries but ignores cons related with this phenomenon.

\section{Research Methodology}

The study is qualitative in nature because it helps to describe comprehensively as well as supports interpretive goals for example to understand the impact of higher education in Pakistan, recognizes the relations between higher education and globalization and highlights the challenges and opportunities created by globalization as well as supports to give recommendations to face these challenges and lessen negative effects and suggests how more benefits can be extracted from globalization.

\subsection{Nature of Data and Data Collection}

The study is qualitative in nature hence qualitative research techniques are used for data collection and interpretation. The data source is secondary in nature. For data collection print and electronic sources are used. Print material like books, published Reports, research journals, Newspapers, previous studies are reviewed and electronic source like internet source in which websites, ebooks, etc. are included are also used.

\section{Data Analysis and Interpretation}

To provide the base for exploration of the impact of globalization on higher education in Pakistan literature was reviewed that also helped in to construct an analytical framework for the study. It also helped in achievement of many objectives for example:

1. Provide base for research design

2. Highlight related studies

3. Diagnose the gaps in former studies

4. Insert more dimensions to questions of research to be inquired (Marshall \& Rossman, 1999).

5. The study operationalizes "Impact" as the opportunities and challenges of higher education in Pakistan in context of globalization. Challenges and opportunities are taken as units of analysis. The first unit of analysis is the challenges those are being faced by higher education in Pakistan in the context of globalization. The second unit of analysis is the opportunities those are created by globalization in perspective of higher education in Pakistan The data were arranged in these two analytical categories. 
6. Impact means effects of globalization that is further divided in opportunities and challenges. Opportunities means advantages and challenges means disadvantages of globalization for higher education in Pakistan.

7. The study is handled analytically and for this the method of integrative review is used. Integrative review is a kind of review in which the writer on a topic explains and comprehends the existing condition of knowledge, describing agreements and disagreements inside it. Mostly it is blend with context review or may be published as a research article for benefit of researchers (Neuman, 2011).

8. Approximately 40 books, research articles, published documents,reports and information collected from library and gathered electronically through websites and internet was reviewed for this studybecause for analytical procedure literature review is prerequisite.

9. According to Creswell (1998) for analysis of qualitative data there are six steps: management of data, reading, describing, categorizing, interpreting, and illustrating.

10. For this study this analytic procedure is used to describe the impact of globalization on higher education in Pakistan.

11. Extensive background research is conducted on higher education and globalization in Pakistan.

12. Both library and electronic searches is included in research process. Analytical procedure started by writing of outline for the study as well as continuously categorizing the data and other literature or information that was required to plan the study.

13. Initial step was to categorize the huge data gathered in a style that it could be used for analysis and for further research.

14. Print and electronic data was organized topic wise and placed them in files.

15. Analytical procedure included to examine the data cautiously as well as record of identified irregularities and errors.

16. Themes and ideas were identified those were related to research questions. Themes were developed in terms of challenges and opportunities in the context of higher education in Pakistan.

17. Analysis of data and progress of categories step by step guided to some growing awareness and conclusions about the impact of globalization on higher education in Pakistan.

18. Opposing point of view was taken from materials and this strategy helped to build an objective approach of the problem and to arrive at 
some conclusion for making recommendations. On the basis of data analysis conclusions are made. At the end recommendations are given on the basis of conclusion.

\section{The Concept of Globalization}

Firstly the term Globalization was used economically but with the passage of time especially in post new world order it has affected not only the economic but also social, cultural as well as political spheres of societies. According to Gidden (1990) globalization is the strengthening of universal social relations who link far off places in such a way that local incidents are influenced by events happening many miles away and vice versa. Waters (1996) defines it as a process in which cultural and social settings are not bounded by geographical boundaries. Marginson (1999) described six trends of Globalization; finance \&trade; communications and information technologies; international mobilization of people; conception of global societies, language, cultural\& ideological union and the world system of Signs and Images. Factors leading to globalization have increased global communication. Multinational companies, free trade agreements and financial markets are providing services around the clock and increasing volume of foreign investment(Deniz,1999).People can acquire quickly and easily information which they require. So, it can be said that students are enjoying the benefits of information technology in process of universalization of education.

\section{Objectives of Global Education}

Every state has its own aim of education that can be changed according to its local needs and requirements but at global level it has global objectives described as following (Deniz, 1999).

- To create skill how to work with people from different cultures

- To learn how to deal with multinational groups

- To instill feelings of globosity instead of individualism

- To acquire skills of new cultures

- To prepare individuals to analyze the happenings in global perspective

- To promote global culture

\section{Globalization and Higher education}

Globalization like other sphere of life also has a deep impact on education. It stresses upon to design national curriculum to fulfill the global needs in perspective of world economy. It also opens opportunities for collaboration in research and teaching institutions at global level (Celik \& Gomleksiz, 2000).Globally education has become a product that moves between states. Because of development of knowledge-based economy competition has 
been started at global level not only among employers for best qualified but even among educational institutions that produce these best professionals. Conventionally students moved from one country to another for advanced studies. Social and economic factors promote cross-border flows as well as competition among countries for foreign students (Arokiasamy, 2011).

Higher education plays basic role in social development and economic progress of a nation. It not only develops intellectual faculty of individuals and train them professionally but also prepares them to understand the changes specially social and cultural change(Gordon, 1999).It is higher education which is no longer a luxury; it is essential for survival. Higher education is the modern world's 'basic education (Jandhyala, 2000).

\section{Higher Education in Global Era and Pakistan}

Globalization evidently creates new opportunities and challenges for higher education (Shahidi \& Seyedi, 2012). For Pakistan in the last two decades, the government's policies to prepare the country to meet the demands of globalized world show that globalization will impact further on the Pakistan's higher education sector .Following are some advantages of globalization for higher education in Pakistan.

\section{Enhance the ability of students}

It develops the capability of students to gain and use knowledge. It also augments the abilities of application, manipulation and judgment of learners (Barker, 1998).

\section{Highly qualified human resource}

Pakistan is trying to improve its education especially higher education system to provide high quality human resources to international market. Pakistan is investing to uplift its higher education to attract the multinational companies for investment and supply them skilled resource persons at cheaper rates as compared to developed countries (Asghar \& Siddi, 2008).

\section{Changing nature of Global Labor market}

In globalized world nature of labor market has entirely been changed. Previously it was only bound to local needs now it is universalized, multifaceted, speedy, and broad and unified that require innovative knowledge. This changing nature is affecting higher education in Pakistan like other developing countries that are trying to compete at global level with scarce resources (Asghar \& Siddi, 2008).

\section{Economic Development}

Advancement in communication especially information technology has built a strong relations between higher education and economic development. 
Technological advancement, inventions and well trained and highly qualified persons are prerequisite for economic prosperity and higher education institutions have a key role to strengthen the economy (Gregor, 2002). So, in Pakistan government is trying to upgrade the university.

\section{Improvement in Quality of Education}

Technological revolution has created the competitive environment among higher educational institutions at national as well as international level that has further forced the governments to improve the quality of education (Shek et al., 2012). So, government of Pakistan is also trying to upgrade the standards of education especially higher education. In this regard higher education commission is playing a very pivotal role and encouraging the mobility of students, offering scholarship especially for M.phil and $\mathrm{PhD}$ programs. Quality assurance, as an important matter in global education, has also focused to meet the demand of global market (Omar, 2006) as well as is trying to introduce new doctoral programs and increasing quantity of students. In Pakistan, quality of higher education is addressed by government in educational reforms and policies gave much importance to it.

\section{Enhancing Access to Global Market}

Previously market was only limited to national boundaries. But now because of globalization it has been extended at global level that is more vast, unified and fast. As a result it created more job opportunities especially for qualified persons of developing countries like Pakistan. A large number of Pakistani qualified professionals are serving in different countries (Hussain, 2015).

\section{Cooperation in Academic Research}

Cooperation in academic research has been increased (Tijsseen,2012). Higher education institutions are busy in promoting research culture and are organizing International conferences, encouraging mobility of researchers, publishing Research journal internationally. Likewise in Pakistan universities are arranging international conferences, workshops, seminars and lectures. Developed nations sponsor the students and researchers and are funding the students for higher education and research in their countries. By their cooperation thousands of Pakistani students and researchers are acquiring education and busy in their research ("HEC to offer 10,000 PhD scholarships for US", 2016).

\section{Use of educational Technologies}

Globalization helps Policy makers and Information technologists to introduce reforms in education and use of educational technologies for exchange of ideas and experiences (Celik \& Gomleksiz, 2000).In Pakistan modern 
technologies are also being used by higher education Institutions. In this regard arrangement of video lectures and conferences are best examples of use of these technologies.

\section{Challenges of Globalization}

Globalization has posed many challenges in Pakistan for higher education that can be described as following.

\section{Commercialization of Knowledge}

There are so many types of globalization in which most prominent is economic dimension. In this perspective education especially higher education, is considered prerequisite for progress and development of market economy (Waters, 1996) that requires those resource persons who can compete in global market. This notion is build upon human capital theory that considers education as an industry instead of propagation of knowledge for moral improvement of human beings. This approach also favors the free market economy that encourages private sector instead of public (Marginson, 1993).The World Bank

Figure 1: Spectrum of Marketisation and Privatisation of Welfare

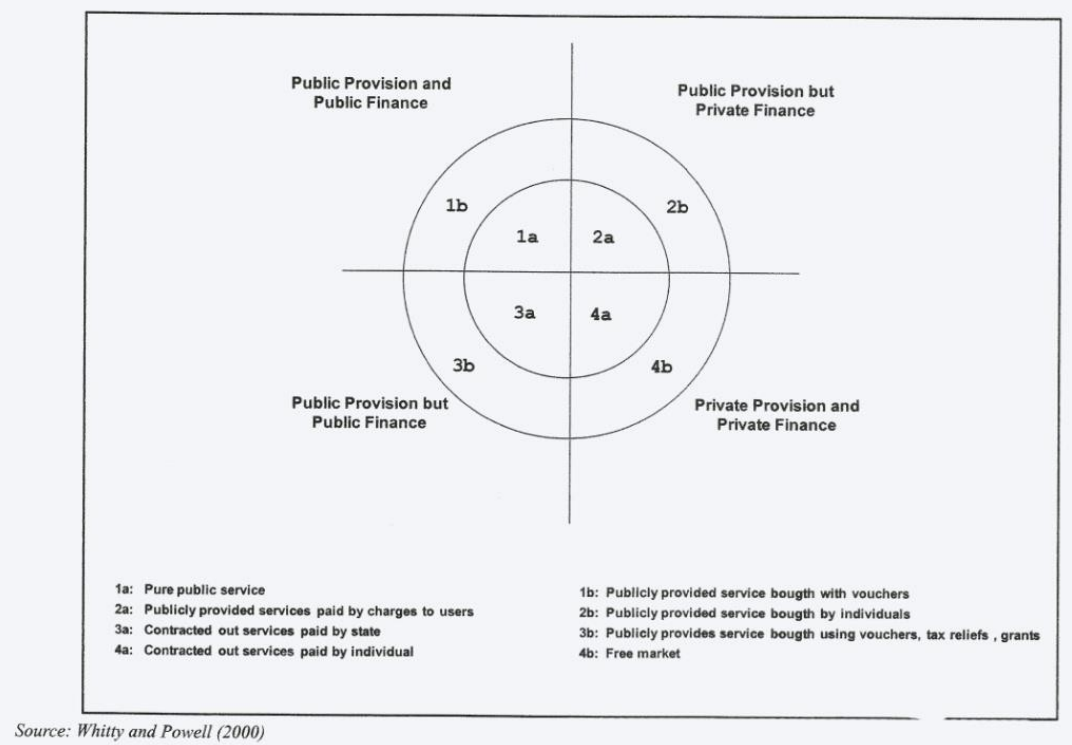

and The Organization for Economic Co-operation and Development are supporting governments to modify their public policy from social to economic good (Currie, 2002). This approach is based upon concept that education should be beneficial at societal level as well as at individual level. Commercialization 
and privatization of knowledge can be explained in following figure.

In this context, education policy is facing pressure from higher to lower level in Pakistan like other developing countries. It is making efforts to preserve its traditional role as a knowledge supplier and at same time as human capital developer. The focus of education policy is shifting from ideological towards development of human capital that is necessary for the market instead of promulgation of knowledge (Ali, 2005).

\section{Brain Drain}

The modern dimension of globalization has been identified as the movement and swap of goods, services, resources, and informative services and highly qualified and trained worker (Sajjad, 2011). Brain drain is a term that means migration of educated, skilled and trained human resources from one country to another for trade, job or education. However majority of migration is from developing to developed countries and it is a very severe issue which must be taken seriously by those countries (Williamson, 2000). Higher education is one of the most important reasons of emigration. Fifty percent foreigner students are settled in European countries like France, Britain and in America even immediate after completion their studies.

According to recent study among 59 million migrants in The Organization for Economic Co-operation and Development countries about, 20 million are highly skilled. Most of The Organization for Economic Co-operation and Development countries possess South Asian countries including Pakistan, Srilanka and Bangladesh. This issue is also directly related with globalization and Pakistan is facing problem like other developing nations. According to a report released by the Ministry of Overseas Pakistan from 1981 to 2012, 5,873,539 people have migrated out of which 41,498 professional and technical workers emigrated in 2012 alone (Hussain,2015).

Settlement of qualified and trained persons abroad gives a setback to Pakistan not only in form of loss of valuable and skilled employees but also bear the extra expenditure of recruitment and training of new recruited persons. Oda (2009) has presented some important facts about Pakistanis in America according to which $60.9 \%$ and $45 \%$ female Pakistani resident of United States of America aged 25 years or above were Graduate or having higher degree. 
Table 1

Number of South Asian immigrants (age 25 and older) to the USA by level of educational attainment, 2000 Total Educational level

\begin{tabular}{lccc}
\hline Country Tertiary & Immigrants & $\begin{array}{c}\text { Primary and } \\
\text { less }\end{array}$ & Secondary \\
\hline Bangladesh & $69,1806,000$ & 20,095 & 43,085 \\
India & $836,78041,185$ & 127,540 & 668,055 \\
Pakistan & $165,42511,630$ & 43,365 & 110,430 \\
Sri Lanka & 2,820495 & 5,695 & 15,630 \\
\hline
\end{tabular}

Table 2

Source (Oda, 2009)

Distribution (\%) of Pakistanis who went abroad through Bureau of Emigration \& Overseas Employment during 1981-2013 by Country of Destination

\begin{tabular}{lc}
\hline United Arab Emirates & 30.8 \\
Saudi Arabia & 51.2 \\
Oman & 8.0 \\
Kuwait & 2.6 \\
Bahrain & 1.8 \\
Qatar & 1.5 \\
Rest of the world & 1.6 \\
\hline All & 100 \\
\hline
\end{tabular}

\section{Academic Imperialism}

Source (Oda, 2009)

Investment on research and development in public and private universities by national and international institutions in developing nations like Pakistan is encouraged to increase the independence of higher education institutions (Beerkens, 2003).

This autonomy gives the freedom especially to private institutions to set or increase tuition fee and free to build their relations. In this background financial aid released by developed countries to higher education institutions give 
way to academic imperialism (Hill, 2007).

\section{Impact of globalization on education policies}

According to Porter \& Vidovich (2000) higher education has been affected by globalization by reducing budget to exchange income resources, introduction of new shape of responsibility and discussion about the role of universities in modern societies. Developing countries like Pakistan has diagnosed the stress of globalization on higher education institutions which are being compelled to change syllabus and struggle for budgets (Mok,2000).They are under the pressure of financial institutions like The International Monetary Fund to take out subsidies in which higher education is also included and financing by private sector is encouraging in this sphere. This "market oriented education system is "promoting Scientific and technical education instead of the social sciences and humanities (Ali, 2005).

\section{Ignoring National Needs}

For the alignment with globalized world the educational policies of Pakistan like other developing Nations are not satisfying national needs. For example free quality Primary education as well as low cost higher education should be provided by government. But because of privatization of education to enhance the free market economy parallel system of education has been emerged in which quality of education is only limited to financially sound class (Monkman \& Baird, 2002).

Like this 4 years BS Honors Program is not according to social and economic environment. Majority of population is living below poverty line (Imran, 2013). Where students after graduation try to find some job or earn something. BS program is primarily to entertain the interdisciplinary approach that can be entertained even in two years.

\section{Promotion of higher education at the cost of primary education}

In globalized world flourishment of higher education as industry in Pakistan government is targeting promotion of higher education and ignoring primary education instead of fact that in Pakistan literacy rate is not encouraging. According to the Pakistan Social and Living Standards of Measurement (PSLM) Survey 2013-14, the literacy rate in Pakistan is 58 \% (2014-15 economic survey of Pakistan). For fiscal year 2014-15 allocation of budget for education was 97.8 billion in which $10 \%$ is allocated for secondary, only $7 \%$ to pre-primary and primary education (Ghani, 2016).

\section{Promotion of global citizenship}

In globalized world national citizenship is in competitive position with global Citizenship especially in developing countries. In this regard world 
political and economic institutions like World Bank and The International Monetary Fund, United Nations pressurized Pakistan and other underdeveloped nations should introduce reforms especially in higher education to meet the demands of global governance and citizenship (Ali, 2005).

\section{Conclusion}

Through this study an effort has been made to explore the impact of globalization on higher education in Pakistan that is considered a base for implementation of multifaceted process of globalization. The research explores that globalization creates opportunities and on the other side gave birth to new challenges for higher education. Higher education institutions and policy makers must be aware of changing global environment and should understand that this modern wind of change neither be stopped nor opposed but can be managed.

Success of one policy in one country is not the guarantee of its successfulness in another country because of different social and economic conditions. Thus to face the challenges of globalization it is need of hour to revise the higher education policies by policy makers and to introduce reforms in global perspective as well as national priorities to survive in globalized world.

\section{Recommendations}

1. To discourage brain drain better opportunities of employment should be created and handsome wages or salary should be paid to highly qualified persons.

2. Resources should be allocated by government for different level of education (Primary, Middle, Secondary, and Intermediate and Higher level) according to national needs not only focusing or setting priority under international pressure.

3. Private universities should be bound by Government of Pakistan to fix maximum fee to entertain economically less privilege students.

4. Government and universities should facilitate mobility of teachers and students across the national boundaries for research and advance study.

5. Scholarships for advance study in a foreign country should be granted by government and higher education commission of Pakistan to students of social Sciences, Humanities and natural science on equal bases.

\section{References}

Ali, S. (2005). The influence of globalisation on the national education policies of developing countries. Journal of Educational Research, 8(1), 14.

Arokiasamy, A. R. A. (2011). An analysis of globalization and higher education in Malaysia. Australian Journal of Business and Management Research, 
1(9), 73.

Asghar, W., \& Siddi, S. (2008).Apprenticeship Training in Pakistan: A Comparative Study of Apprenticeship Practices in Punjab and European Countries. International Journal of Training Research, 6(2), 1-19.

Barker, K. (1998). Serving the learning needs of education consumers. Education Canada Winter, 38(4), 25-27.

Beerkens, E. (2003). Globalisation and higher education research. Journal of Studies in International Education, 7(2), 128-148.

Çelik, V., \& Gomleksiz, M. N. (2000). A critical examination of globalization and its effects on education. Firat University Journal of Social Science, $10(2), 133-144$.

Crawford, P. (2003). Captive of the System! Why Governments Fail to Deliver on Their Promises-and What to Do About It-David Burchell. Australian Journal of Public Administration, 62(2), 124-126.

Creswell, J. W. (1998). Qualitative Inquiry and Research Design: Choosing Among Five Traditions. North California: Sage Publications.

Currie, J. (2002). The Neo-Liberal Paradigm and Higher Education: A Critique, in Odin and Development in the 21stCentury. Westport: Greenwood Press.

Deniz, N. (1999). Global Education. Istanbul: Turkmen Press

Giddens, A. (1990). The consequences of Modernity: Self and Society in the Late Modern age. Stand ford calif: Standford University Press.

Ghani, A. (2016, April 14). PhD-holders 'fleeing'Balochistan. The Nation, p.12.

Gordon, G. (1999). Managing the changes inherent in developing the Learning Society: issues, choices and strategies. Quality Assurance in Education, 7(3), 141-149.

Gregor, A. D. (2002). Globalization, trade liberalization and higher education: Research areas and questions. Occasional papers in Higher Education No, 10. Retrieved from https://scholar.google.com.pk/scholar

HEC to offer 10,000 PhD scholarships for US. (2016). DAWN.COM. Retrieved 29 January 2016, from http://www.dawn.com/news/1282794

Hill, D. (2007). Educational perversion and global neoliberalism. In Ross W. \& 
Gibson R. (Eds.), Neoliberalism and education reform (pp.107- 144). New Jersey: Hampton Press.

Hussain, T. (2015, 25, December). Brain Drain. Daily Dawn. Imran, I. (2013, January 3). Poverty in Pakistan. The Nation, p.7.

Jandhyla, B.G.(2000). Higher Education in Developing Countries. Minerva, 2(38), 233-240.

Marginson, S. (1993). Education and Public Policy in Australia. Melborne: Cambridge University Press.

Marginson, S. (1999).After globalization: Emerging politics of education. Journal of education Policy, 14(1), 19-31.

Marshall, C. \& Rossman, G. B. (2014). Designing qualitative research. Chapelhill: Sage publications.

Mok, K.H. (2000). Reflecting globalization effects on local policy: Higher education reform in Taiwan. Journal of Education Policy, 15(6), 637660 .

Monkman, K., \& Baird, M. (2002). Educational change in the context of globalization. Comparative Education Review, 46(4), 497-508.

Mundial, B. (2000). The Task Force on Higher Education and Society. Higher Education developing Countries: Peril and Promise, Washington, The World Bank.

Neuman, W. (2011).Social Research Methods: Quantitative and Qualitative Approaches. New Delhi: Pearson.

Oda, H. (2009). Pakistani migration to the United States: An economic perspective. Retrieved from http://hdl.handle.net/2344/839

Omar, N. (2006). Globalization and Higher Education in Pakistan. Economic and Political Weekly, 41(49), 5080-5085.

Porter, P., \& Vidovich, L. (2000). Globalization and higher education policy. Educational Theory, 50(4), 449-465.

Sajjad, N. (2011). Causes and solutions to intellectual brain drain in Pakistan. The Dialogue, 6(1), 31-55.

Shahidi, N., \& Seyedi, S. M. (2012). The Impact of Globalization in Higher Education on the Universities' Educational Quality: A Regional Project 
on Shiraz Universities. World Applied Sciences Journal, 20(9), 13001306.

Shek, D., Sun, R., Chui, Y., Lit, S., Yuen, W., Chung, Y., \& Ngai, S. (2012). Development and Evaluation of a Positive Youth Development Course for University Students in Hong Kong. The Scientific World Journal, 2012, 1-8. http://dx.doi.org/10.1100/2012/263731

Tijsseen, R. (2012). R\&D globalization Processes and University Industry research cooperation: measurement and Indicators.

Retrieved fromhttps://www.Cwts.nl/pdf/CWTS-WP- 2012-
009.pdf

Waters, M. (1996). Globalization. London: Routledge.

Williamson, J. (2000). What should the World Bank think about the Washington Consensus? The World Bank Research Observer, 15(2), 251-264. 